\title{
Exploring newspapers' portrayals: A logic for interpretive content analysis
}

\author{
FRED WESTER, ALEXANDER PLEIJTER and \\ KARSTEN RENCKSTORF
}

\section{Abstract}

As shown through an inventory of the procedures used in diverse forms of qualitative content analysis projects, the logic of qualitative procedures is in most cases not standardized. Often researchers pay little or no attention to the procedures which they apply. This contribution presents and discusses a procedure for interpretive content analysis which was applied in an empirical study into trans-border news coverage in the Dutch-German Euregion Rhine-Waal. First, we will describe the study on the portrayal of the Dutch and German people as well as their respective countries, The Netherlands and Germany, in the four main regional newspapers of this region. Secondly, basic principles of qualitative methodology are discussed and, thirdly, the procedure of the applied method based on these principles is presented and illustrated by means of exemplary material. Finally, after a brief presentation of some empirical results, the applied procedure of interpretive content analysis is discussed.

Keywords: content analysis, communication science, audience centered approaches, interpretive content analysis, logic, newspapers' portrayals

Content analysis is a research method closely related to communication science. Especially the development of audience-centered approaches in communication science, stressing amongst others the 'meaning-making', i. e., the interpretive, capacity of media users, has generated numerous research questions that call for interpretive research methods (Anderson, 1987; Altheide, 1987; Jankowski and Wester, 1991; Lindlof, 1995; Renckstorf and Wester, 2001). As a result we see - apart from the application of widely accepted forms of quantifying content analysis - a growing number of studies using various forms of qualitative content analysis. For example, empirical studies on the problem of newspapers' image forming and newspapers' construction of national identity (e. g., 
Mellinger, 1992; Alexander, 1994; Shaheen, 1994; Tudor, 1992). Besides studies using more traditional procedures in which the images newspapers present are reconstructed by correlations between textual parts (cf. Krippendorff, 1980; Früh, 2001), one can witness an expansion of studies aimed at describing image-formation in terms of its content by reconstructing the structure of the text and its verbal repertoires (sometimes referred to as frames or discourses).

The reconstructed logic of qualitative procedures in content analysis is, however, in most cases not standardized (Hijmans, 1996). Most often researchers pay little or no attention to the procedures which they apply (e. g., McAllister, 1992; Lupton, 1993; Hardt-Mautner, 1995; Waisbord, 1997; Vavrus, 1998; Deutchman and Ellsion, 1999; Triece, 1999), and some of them even regard their method of content analysis as an intuitive form of close reading that cannot be explained any further. Others only present a scant account of the methods used. An inventory of procedures applied in diverse forms of qualitative content analysis projects (Pleijter, forthcoming) suggests that methodological accounts most often boil down to a mere indication of the research material or a general reference to Glaser and Strauss (1967). None of the studies inventoried provided an elaborated account of a particular procedure or logic of the method applied.

In this contribution we will present a procedure for interpretive content analysis we developed and applied in the context of a study on trans-border news coverage from the Dutch-German Euregion RhineWaal (Renckstorf et al., 2004). First we will discuss the design of the three sub-studies devoted to the investigation of trans-border news coverage and to the reconstruction of newspapers' portrayals of the Dutch people, The Netherlands, Germans and Germany. Next, we will discuss some basic principles of qualitative methodology, present the procedure of our method based on these principles and illustrate them by means of exemplary material. After a brief presentation of results, we will discuss the applied procedure of interpretive content analysis.

\section{'Communication across the border': A study on trans-border news coverage by Dutch and German newspapers, 1946-1999}

The research project 'Communication across the border' ('Kommentare und Berichte von der anderen Seite der Grenze'1) aims at the investigation of the trans-border news coverage by Dutch and German daily newspapers published in the Dutch-German Euregion Rhine-Waal between 1946-1999. In the Dutch part of the Euregion Rhine-Waal there are two main newspapers that have appeared throughout the whole period; i. e., De Gelderlander and Dagblad van Noord-Limburg. On the German 
side there are also two main dailies, Rheinische Post and Neue Rhein Zeitung whose trans-border news coverage was included in this study.

The project on the trans-border news coverage of these four newspapers consists of three research phases or three sub-studies, each with their own objectives, designs and research methods:

- The first phase of the research project, called the trend study, aimed to identify trends in trans-border news coverage during the whole period after World War II up to now. It was administered using a systematically quantifying form of content analysis in order to investigate the number and scope of records, thematic contents, but also journalistic forms and formats.

- The second research phase, called the region survey, was designed to provide us with up-to-date insights into number, scope, form and thematic contents of the contributions of regional news coverage of these four newspapers, More specifically, this research phase uses qualitative content analyses to gain an insight into the regional news coverage of the four papers in October 1999.

- The third research phase, the so-called case study, aims at investigating newspapers' portrayals of Dutch and German people as well as their respective countries. In this phase, special thematic cases of trans-border news coverage were studied by means of a qualitative content analysis in order to explore the newspapers' portrayals of said topics. The analysis focused on the news reports in all four papers of historically relevant events that were related to the German-Dutch relations throughout the period 1946-1999.

In this contribution we will focus on the presentation and discussion of objective, design and development of an appropriate research method for the third research phase of the above-mentioned project, i.e., the case study.

\section{Research objective and design of the case study: A study on newspapers' portrayals}

The case study was designed to investigate and systematize the imagesetting aspects of the papers' news coverage of relevant events concerning the often somewhat problematic Dutch-German relationships during the last 50 years (Renckstorf and Janssen, 1989; Renckstorf and Lange, 1990; Jansen, 1993; Westheide, 1997; Von der Dunk, 1994; Dekker and Aspeslag, 1999). This qualitative aspect of the papers' news reporting was explored by means of an interpretive form of content analysis.

The case study focuses on specific events within five topic areas of special, exemplary relevance for the Dutch-German relationships, which 
further on are indicated as cases. The reason for this was that we expected that image-setting aspects, i. e., evaluative portrayals of the Dutch and the German people as well as portrayals of The Netherlands and Germany, would especially come to the fore in the papers' news coverage on major news events, that is, news events of crucial importance for the German-Dutch relationship. The following events stemming from five topic areas were chosen:

1) within the topic area of politics, we selected and analyzed the total news coverage of the four newspapers on six official state visits since World War II;

2) within the topic area of economics, the papers' coverage on two events of business fusion: the merger of Hoogovens (Dutch) and Hoesch (German), two steel plants, in the 1970s, as well as the merger between airplane manufacturers Fokker (Dutch) and Dasa (German) in 1992, were selected and analyzed;

3) within the topic area of post-war history we analyzed the news coverage on the German Second World War criminals that were released from the Dutch prison in Breda in 1989, known as 'Four/Three/Two from Breda', who up to that time had been detained in The Netherlands;

4) within the topic area of sports we analyzed the papers' coverage of international football matches between The Netherlands and Germany, i.e., FRG as well as GDR; and finally

5) from the topic area culture we selected an item about the Frankfurt Book Fair in 1993, the focus of which was on 'Literature from The Netherlands and Flanders.'

The papers' news coverage of these events was studied from the imagestetting perspective, and thus the following questions had to be answered: How are these events and their contexts presented in the papers' news coverage? What is the nature of the portrayals of The Netherlands and Germany, of Dutch people and of Germans, that are created in the news reports and, which aspects of image-setting by the papers are detectable?

The four newspapers covered the events in a variety of diverse genres: articles, commentaries, columns, photos, interviews, cartoons and the like. Since the case study was designed to allow for a mutual comparison of those news items with respect to various aspects of image-setting, we constructed a comparative research design of multiple case studies (cf. Yin, 1994). 


\section{Sample}

Having prepared a list of real-world events and the historical date of the event (year, month, day), the newspapers were monitored for coverage on this event. As a rule, we looked for items in issues published one week before and one week after the events. In a number of cases we made an exception, for instance in the case of international football matches between The Netherlands and Germany, as most of these matches took place in the context of tournaments of World or European championships. In these cases we did not monitor an entire week before and after the match, but just the coverage which appeared between the previous and the following match played by the national football teams. More specifically, the news coverage we studied concern the following events (in brackets: year of event and year of news reporting):

1) Dutch-German State visits (1964, 1993, 1994, 1995, 1998),

2) The rise and fall of the Dutch-German business merger Fokker-Dasa (1992, 1996),

3) The release of German POWs (1966, 1972, 1979, 1989),

4) The Frankfurt Book Fair 1993 (1993),

5) The football matches between The Netherlands and Germany (1956, 1961, 1974, 1978, 1980, 1988, 1990, 1992).

The sample of the case study consists of a total of 1061 news items, including 429 items published by De Gelderlander, 307 by Het Dagblad voor Noord-Limburg, 179 by Rheinische Post, and 146 items published by Neue Rhein Zeitung.

\section{Methodological principles}

Before presenting the steps of the procedure, the logic of the qualitative content analysis applied in the case study; i. e., the methodological background, will be outlined first. Of course, there are many variants of social science research, and this holds also true for the category of qualitative studies. There are important differences concerning the concrete procedures applied in ethnographic research on (sub)cultures, case-study research, participant research in organizations, intensive interview studies on processes of interpretation or meaning giving, biographical research or conversation analysis (cf. Wester, 1995). While all of these forms of qualitative research seem to refer at least partly to differing scientific traditions, they share a number of common methodological principles that underlie their research activities. 
A basis assumption is that social scientists encounter a reality which is already endowed with meaning by those involved in it. That is, actor perspectives play a role in the situations under investigation and as such they must become part of researcher's analytical framework. Consequently, there is a need for a participating research approach through which the life-world of the people involved can be integrated into the research perspective. In order to realize this, the researcher starts with a rough framework of sensitizing concepts, which is empirically elaborated by studying and comparing ('constant comparison') strategically chosen observation situations ('theoretical sampling') in such a way that the perspective fits the reality under investigation and that the research questions can be answered (Glaser and Strauss, 1967; Glaser, 1978; Strauss and Corbin, 1990; Wester, 1995). The process of elaboration of the analytic framework is directed by constantly recurring phases of reflection (Glaser, 1978; Wester, 1995) which give direction to observation, analysis and validity controls (for example by 'triangulation', or 'replication'). These general principles have been further expanded for ethnographic research (Spradley, 1980), interaction-studies (Strauss and Corbin, 1990), and interview-studies (Wester, 1995; Wester and Peters, 2000) into stepwise procedures with cyclically alternating periods of observation, analysis, and reflection.

These general principles can also be used to shape procedures for qualitative content analysis. The reconstruction of the actor perspective is relevant here, since it enables the researcher as a cultural member to summarize the reporting on an event in terms of people, activities, and relevant themes. By subsequently reading and re-reading the news coverage from the perspective of the sensitizing concept image-setting and focusing on the way in which people, acts, and events are presented, and through the comparison within and between the reports in these respects, the researcher is able to formulate case specific interpretation frames that can explain the appearance of evaluative or identifying characteristics of the Dutch people and the Germans, as well as The Netherlands and Germany, in the newspapers' news coverage.

Next, we will present the logic of the qualitative content analysis applied in the case study, which is based on these principles of interpretive research.

\section{Steps in reconstructing newspapers' portrayals}

In order to analyze newspapers' portrayals of the Dutch and German people as well as their respective countries, five real-world events of some relevance for the Dutch-German relations were selected as described 
above. The news reports, i. e., all single items of news coverage on these events, were subsequently analyzed using the perspective of image-setting, that is, by reading and re-reading the papers' reports on the given real world event. The process of reading occurred with special regard to the way persons, acts, and events are presented, and by comparing (within and between) the single reports in these respects, the researcher comes to formulate a case-specific interpretation frame. These three steps allow for explaining the appearance of evaluative or identifying characteristics of the Dutch and the Germans and their respective countries as published in the papers' news coverage.

All articles and news items that focused on the events in the given period were photocopied, stored and read by one of the researchers according to the following procedure. The item selection procedure yielded a comprehensive collection of diverse kinds of news reports, ranging from articles to columns, photos, cartoons, etc. The phenomenon of image-setting becomes apparent, as certain characteristics of events or actors involved are related systematically in one way or another to 'Germany' or 'The Netherlands' (or 'Holland'), or to 'Germans' or 'the Dutch', respectively. As expected, each series of articles has its own dynamic in terms of relevant semantic aspects and elements of portrayal related to them. Therefore, the researcher first has to read an entire series of articles about a given event in order to comprehend the course of reporting. For example, the coverage of an international football match between the teams of West-Germany and The Netherlands during the World Football Championship in 1978 contains themes interconnected with this particular context (such as previous matches, quality of football players, political events in Argentina, etc.) in which image-setting and portraying can emerge in very peculiar ways. These aspects of imagesetting have been retrieved in a comparable manner for all news items under investigation. Subsequently, the researcher has to register the necessary information in a research protocol - according to the procedure described below - and produce tables and overviews to select relevant parts of the texts. Comparisons within and between these overviews enable the researcher to describe interpretation frames and images related to newspapers' portrayals of 'the Dutch' and 'the Germans', as well as their respective countries.

In detail, the researchers have read the news reports along the following procedure, a guide-line consisting of eight steps.

Step (1): Reading the whole series of news reports on a given event Reading a complete series of news reports is an indispensable step in 
learning about relevant actors, places and themes, as well as the related verbal repertoire published in the reports on the selected event.

Step (2): Description of the overall subject of the series of news reports This description is simple and based on the reading of a series of news reports. A description of the first series of news reports - concerning the case of state visits - for example, reads as follows:

Chancellor of the Federal Republic of Germany Erhard and Foreign Minister Schröder visit The Hague (Feb-March 1964).

Step (3): Summarizing the content of the whole series of news reports This summary uses information stemming from the series of news items about actors, places, substantive themes and circumstances. The summary constitutes the context for step (4), i. e., it serves as a neutral semantic structure against which image-setting can be outlined. For the above example the summary reads as follows:

On March 2nd and 3rd, 1964 the Chancellor of the Federal Republic of Germany, Ludwig Erhard, together with Foreign Minister, Gerhard Schröder, and State Secretary for Foreign Affairs, Lahr, pays a visit in The Hague to Prime Minister Marijnen and foreign minister Luns. Main subject of reports is the future of European co-operation. Erhard worries about an attitude of some of the countries in respect to European political and economic integration. Especially the role of Great Britain and France is a sensitive issue. The Dutch government recognizes that Britain has to be involved in the forming of a political union from the very beginning. France (de Gaulle), on the contrary, would rather ignore Britain. Erhard visits the Dutch government in order to make progress in this controversy. The Dutch and the German governments seem finally to agree about the issue.

Step (4): Re-reading the news reports and marking image-relevant textual passages

The point is to focus the re-reading on segments of the text which can be related to image and portrayals. Especially relevant are here: Oppositions, evaluative expressions, value judgments, assessments, labeling, metaphors and other relevant formulations, such as comparisons and terms derived from domains of activity other than an analyzed event, as well as the use of German words (in Dutch newspapers) or Dutch words (in German papers). These are, as it were, extra meanings added to a more or less neutral semantic structure, as depicted by step (3). These kinds of textual passages characterize actors and their actions, and situate actors and activities in mutual relations. Image-setting emerges as 
these types of evaluations or characterizations are indirectly connected with German/Germans/Germany or Dutch/Dutch people/The Netherlands. Of course, direct connections do appear too, therefore all passages in which such terms as German/ Germans/ Germany or Dutch/Dutch people/The Netherlands or variations thereof are taken into account as well. For example, in an 800-word comment published in the Dutch paper, De Gelderlander (28 ${ }^{\text {th }}$ of February 1964), the following passages were marked:

'Herr Bundeskanzler' ... Erhard ... will ... develop initiatives in The Hague which ... may mark fundamental progress ... the breath of the Dutch lion ... also in the interest of The Netherlands ... let's hope he is granted - at least some success.

The passages contain an expression derived from German ('Herr Bundeskanzler'), two positive qualifications of Erhard ('initiatives', 'fundamental progress'), two text segments about The Netherlands ('breath of the Dutch lion', 'interest of The Netherlands') and a positive qualification ('some success') related to Erhard (German Chancellor at that time). Apparently, some news items contain only little or even no text elements relevant for the portrayal of The Netherlands or Germany. On the other hand, there are other news reports, which do contain some or even many textual elements significant for image-setting.

\section{Step (5): Inventory of the news reports' headlines}

The overviews of headlines and image-relevant textual passages is meant to be the starting point for defining a framework of meaning that is important for the exploration of newspapers' image-setting. For this purpose it is necessary to juxtapose the inventoried headlines and fragments as well as to indicate their context. Such overviews can be used for comparisons between events, between cases, as well as between newspapers. Moreover, these overviews can be read by multiple researchers, thus subjecting interpretation to validity controls. The overviews, therefore, constitute the reduced data material for the interpretive analysis. For each news event, that is, for each series of news reports on one of the five selected cases, a research protocol was produced containing the following three documents:

a) General subject identification and summary of a series of news reports. An example has been given above when explicating step 3 .

b) Overview of news reports per event in terms of publication date, headline and position in the newspaper. For the series of eleven items 
of news reporting on State Visits, published by De Gelderlander in February and March 1964 our document looks as follows (see Table $1)$.

Table 1. Inventory of the headlines of a series of eleven news reports on 'state visits', De Gelderlander, Spring 1964.

\begin{tabular}{|c|c|c|c|}
\hline nr. & date & headline & \\
\hline 01. & 280264 & The Hague awaits Erhard (commentary) & p. 4 \\
\hline 02. & 280264 & $\begin{array}{l}\text { Visit Erhard in The Hague: new impulses for political } \\
\text { ECM-Union }\end{array}$ & p. 7 \\
\hline 03. & 290264 & $\begin{array}{l}\text { Question Spijk and Dinxperlo presented to Federal } \\
\text { Chancellor }\end{array}$ & front page \\
\hline 04. & 290264 & $\begin{array}{l}\text { I come to The Netherlands to show the new democratic } \\
\text { Germany }\end{array}$ & p. 3 \\
\hline 05. & 030364 & $\begin{array}{l}\text { Dutch-German talks finish: top conference of six not } \\
\text { necessary any more }\end{array}$ & front page \\
\hline 06. & 030364 & Prof. Erhard in The Hague & p. 4 \\
\hline 07. & 030364 & $\begin{array}{l}\text { Oranje Nassau for Dr. Schröder: German distinction } \\
\text { for Mr. V. Marijnen }\end{array}$ & p. 7 \\
\hline 08. & 040364 & $\begin{array}{l}\text { Bonn-The Hague: optimal agreement; Erhard: political } \\
\text { will in Europe is what we need; Marijnen and Luns on } \\
\text { return visit in Bonn }\end{array}$ & front page \\
\hline 09. & 040364 & Erhard does not know Don Carlos ... & front page \\
\hline 10. & 040364 & Not a word on Spijk and Dinxperlo & front page \\
\hline 11. & 060364 & Gravity point (commentary) & p. 3 \\
\hline
\end{tabular}

c) Overview per series of marked image-relevant fragments from all news reports on the given event. An example is given in the following table (see Table 2).

Step (6): Formulation of the interpretive frameworks

The inventories of newspaper headlines (cf. Table 1) provide appropriate overviews which allows for insights into the nature of the verbal repertoires accompanying the news reporting on the given event.

The headlines on the Case of the Fokker/Dasa fusion contained predominantly a family terminology, such as 'daughter', and 'mothercompany'.

Subsequently, we identified the most important actors, topics and/or oppositions, as well as the ways in which actors are connected to them, and the evaluative expressions used in the image-relevant fragments. Thus, it was possible to reconstruct an interpretative framework as well as the verbal repertoires related to the news item. Against this background we analyzed the image-related fragments tracing properties ascribed to the 'Germans' and the 'Dutch', respectively. 
Table 2. Inventory of image-relevant fragments, stemming from a series of eleven news reports on 'state visits', De Gelderlander, Spring 1964.

1. 'Herr Bundeskanzler' ... Erhard ... will ... develop initiatives in The Hague which ... may mark fundamental progress ... the breath of the Dutch lion ... also in the interest of the Netherlands; let's hope he is granted - at least - some success.

2. West German Chancellor and the Dutch government will come to terms about efforts at creating a Political Union. - In honest and true talks ... in what regions there are hindering differences which make a rapprochement impossible ... also want to discuss 'the past'. - The first official visit to the Netherlands of the head of West German government after the war.

3. [About Erhard:] An exuberant type rather just than what we take for a goodhumored German ... 'A real democrat.' - that we, Dutchmen, can 'get on' with him [Erhard] considerably better than with der Alte [Adenauer]. ... in Heine's words: 'Denk' ich an Europa in der Nacht; bin ich um den Schlaf gebracht.' Dr. Erhard says that despite the fact that in the times of the Third Reich he was in the opposition, he is aware that in The Netherlands he cannot behave as if this miserable period which our country too suffered so tragically did not happen, and that he has courage to speak up honestly about that problem that is (still) alive in memory ... I come to The Netherlands to present a new Germany, a democratic Germany, as it began with Dr. Adenauer ... improvement of Dutch-German relations ... for tactical reasons, as a German, he would not rather point to himself. In West Germany not much is said about political or political controversies between Catholics and Protestants. ... Head of West German government ... who makes most pleasant impression ... also as a competent economist but first of all as a person and a good neighbor, is a welcome guest.

4. - (no entry)

5. Quite remarkable unanimity about the European ... As for main lines of the European politics the Dutch and German governments - to quote Minister Luns' words - 'totally agree ... Federal Chancellor has once again received a clear confirmation that The Netherlands supports the idea of German unification. ... is highly satisfied with good relations between both countries. - Minister Luns ... 'the talks take place in a very good atmosphere. Admittedly, relations between West Germany and The Netherlands are perfect.'

6. For the first time since the First World War a head of German government sets his foot on the Dutch soil. It was also for the first time that the German anthem sounded, very officially ... 'to present the new democratic Germany' - began ... the 'Deutschland, Deutschland über alles'. - The guard of honor had never been inspected so 'gründlich' as it was by the German Chancellor.

7. - (no entry)

8. Chancellor Erhard said ... perfect accord ... The Netherlands and West Germany want to go in unanimity and in this way set an example for all other nations in Europe. - Prof. Erhard ... pointed to the fact that perhaps the past could not be erased but that the new Germany deserved trust.

9. - (no entry)

10. - (no entry)

11. That West Germany takes an essential position in the nascent Europe ... a high degree of accord about the European unification. That Prof. Erhard came to our country. Doing so West German Federal Chancellor has doubtless made a step forward; for us, Dutchmen, it is still so difficult to forgive Germans the period in which they caused our nation unspeakably much grief. In this way he made the term 'good neighborliness' into something more than merely a platonic concept or a formality. 
In this way, the news reports on the case of state visits, published by $D e$ Gelderlander in February-March 1964 (cf. Tables 1 and 2) were annotated in the following manner:

The coverage is of relatively considerable scope (cf. Table 1), among others because the case concerns the first official post-war visit to the Netherlands by the head of West German government. Headlines betray a degree of reserve (The Hague Waits for Erhard, Visit to The Hague, Erhard in The Hague), with a positive tinge about mutual relations (new impulses, the new democratic Germany, optimal agreement).

Image-relevant fragments (cf. Table 2) manifest two meanings. One accent lies upon the theme of politics related to European Unification, about which mutual relations between the Netherlands and Germany can be described in increasingly positive terms (progress, some success, come to terms, remarkable unanimity, totally agree, perfect accord). The second theme concerns DutchGerman relations in the light of 'the past' (the war, the period [of] grief). The accent here lies on the positive contribution of Erhard as a government leader of the new Germany (honest talks, rapprochement, first official visit, new democratic Germany, real democrat, the New Germany, good neighborliness) and personal characteristics of Erhard (exuberant type, get on better with [him] than with der Alte, competent economist, a welcome guest, who inspects the guard of honor 'gründlich').

Step (7): Comparison of the detected interpretive frameworks of various series of news reports, and description of newspapers' portrayals or images per case

Having described various series of news reports in the manner sketched above (cf. steps 1 to 6), the researcher can prepare a case specific description with regard to portrayal or image aspects; for example, by including all the news reports on the six state visits. This results in a case-bound repertoire of typologies or labels concerning 'Germany', 'The Netherlands', 'Germans' or ' the Dutch' - including possible changes that were recorded over time. This way, the researcher can trace portrayals or images latent in the news coverage. Comparisons of these portrayals or images of the newspapers within and between the two countries are possible as well.

With regard to our example - the news reports on the case of state visits - published by the Dutch papers De Gelderlander and the Dagblad voor Noord-Limburg, the researchers came to the following case specific description of the image of 'Germany', 'Germans', 'The Netherlands' and 'Dutch people', respectively:

A latent form of image-setting which emerges concerns the positive co-operation with Germany. This is important for The Netherlands because politically 
and economically Germany is a big (strong) neighbor. The Netherlands (as a trading nation, a transit country) is dependent on Germany.

Moreover, in two cases, considerable attention is paid to the theme of the Second World War and the occupation period. On the occasion of the visits of both Erhard (1964) and Kohl (1995) this theme takes up a prominent place; one time it is mentioned in the context of Lubbers. The image-setting points refer to the former Nazi Germany (the Third Reich, Nazi terror, war machine, crimes) contrasted with the present 'new', democratic Germany of today which has so much in common with The Netherlands. Here, image-setting involves also the Dutch people and, especially the youth: they have anti-German sentiments based on ignorance.

Step (8): Comparison of images between various cases - and newspapers The theme-bound portrayals or images per case, as developed and discussed in step (7), constitute but the point of departure for a general description of the newspapers' portrayals or images. These general descriptions of the portrayals or images delivered by the papers can serve as a solid basis for the comparison of the newspapers in this regard.

In the following, we will comment on this problem of comparing portrayals and images between various cases, and, between newspapers as well, by presenting and discussing some exemplary findings of the case study.

\section{Some results and exemplary findings of the 'Cases Study'}

In order to illustrate the kind of results the above- outlined procedure for interpretive, qualitative content analysis may produce, a brief overview of some exemplary findings of the case study - limited to the portrayals of 'the Dutch' and 'the Germans' and their respective countries published by the Dutch newspapers - is provided .

\section{Case 1: Dutch-German state visits (1964, 1993, 1994, 1995, and 1998)}

State visits (46 news items) are predominantly reported from the perspective of political-economical connectedness. The main actors are the Dutch and the German governments and much attention is paid to the mentioned Chancellor of the Federal Republic of Germany. Over the years, both Dutch papers accentuate:

- very "good political relations" between the two countries - despite (just) "occasional disagreements" about political issues. Image-setting that emerges concerns first of all the good cooperation with Germany. For The Netherlands, this is important "politically" and "economically", as Germany is a "big neighbor".

- The Netherlands (as a "trading nation", a "transit country") is "dependent" on Germany. 
- Apart from that, in two cases a historical aspect of the Dutch-German relations surfaces: The theme of the World War II and the "period of Nazi German occupation of the Netherlands 1940-1945".

Case 2: The rise and fall of the Dutch-German business merger FokkerDasa (1992, 1996). The most important actors in the news coverage on the Fokker-Dasa case (126 news items) are the Dutch government, the German enterprise Dasa and the Dutch aircraft factory Fokker. The perspective applied concerns a financial-economic question with European and multi-international dimensions.

- Although on the Dutch side this case represents a problem on the national level (state shares, employment) the verbal repertoires applied in headlines concern "agony", "social drama" and "financialeconomic loss" of international proportions.

- The fact that Dasa is a German company and that the negotiation partners are German recurs throughout the entire coverage of the case. In a background story about a Fokker manager, sensitive relations are mentioned (“... die Niederländer sollen endlich den Krieg vergessen") but the final dissolution of the fused enterprise is described in family terminology (German "mother", Dutch "father"). In March 1996 the newspapers still refer to Fokker's "German past".

Case 3: The release of the German POWs from the Breda prison (1966, 1972, 1979, 1989)

The newspaper reports on the case of the "German Prisoners of War from Breda" (155 news items) thematize the "dissent" in "Dutch society and politics".

- Image-setting with regard to this case is, thus, not directed towards the Dutch-German relations but to "internal Dutch relations". It is mainly geared towards the relationship between politics and war victims, and shows the inhuman character of war criminals and the "suffering of war victims" as a background theme. The period of WW II is discussed here by thematizing the experiences of war victims, and by describing the harm done by not only the criminal Nazi regime but also by Dutch politics before and after the war.

\section{Case 4: The Frankfurt Book Fair 1993 (1993)}

In the case of the Frankfurt Book Fair in 1993 (8 news items), Dutch literature is the leading theme. The image-relevant fragments published in the Dutch papers are limited to some German words ("Eröffnungsredner", "Schwerpunkt", "Messegelände”, "Neue Bundesländer”). 
Case 5: The Football matches The Netherlands vs. Germany (1956, 1961, 1974, 1978, 1980, 1988, 1990, and 1992)

The news coverage on the international football matches (401 news items) is characterized in the early years by the metaphor of struggle or even war. The reports of the Dutch papers abound in German words and expressions, especially since 1988 (such as "Blitzkrieg", "himmelhochjauchzend", "enttäuscht", "Hals- und Beinbruch", "Mannschaft", "Wir-Gefühl", "gibt es keinen Tag so wunderschön wie gestern und heute und morgen", "National-Gefühl", "Deutschland über alles", "deutscher Kampfgeist", "heisse Spiele", "erbarmungswürdige Antifußballer").

- Image-setting elements concerning the German national football team are: "Commitment", "running fitness", "endurance", "fighting spirit", "force", "speed", in some cases "mentally strong", "experienced", "businesslike and cool", "professional", "correct", "tough but fair", but in hindsight it turns out to be "a poor team", "not better but just more cold-blooded", with a "timid fighting technique", "with more force and also good luck", "a defensive or cowardly tactic", and first of all the "luck" on "the part of The Netherlands' greatest rival".

- The Dutch football team is characterized as being: "Self-assured", "of devastating superiority", "beats the big drum" and is "better technically", "plays modern football", but on the other hand "bad in defense", "too phlegmatic", "world stars", "alternating brilliant football with poor results"; they never fail, at most things do not go the Orange way ("the field, the ball, a stroke of good luck for Germans").

Comparing the images as they emerge in these five cases of the Dutch papers' news coverage, as described above, the relationship with Germany can be represented as one with a strong big brother with a dirty past.

In both Dutch newspapers, Germany is associated with a double meaning structure. On the one hand the Federal Republic of Germany, the Germany of today, with which you cannot find anything wrong ("shows reserve", "condemns war criminals") which has so much in common with The Netherlands and with which The Netherlands can cooperate very well. On the other hand the Germany of the past ("Third Reich", "Nazi terror", "war machine", "crimes", "the war" and "Nazi times") when the inhuman were at power.

The Netherlands emerge in the Dutch papers' news reporting as a "divided country" (for and against release, government versus war vic- 
tims) that punishes inhuman behavior with inhuman punishment ("life sentence"), and one with a tainted past ("betrayal of the Jews"). Here, one object of image-setting are the Dutch themselves and especially the Dutch youth; their anti-German sentiments are based on ignorance since they do not know the new Germany.

The double meaning structure in relation to Germany returns in the images of Germans: a "great culture", "economical world power", "hard workers", "very precise", "perfect finish", "arrogant", conducting the "German Way of Thinking". Dutch newspapers' images of the Dutch refer to "tradesmen", "penny-pinchers", "patronizing" as well as "loose morals", always mentioning the Second World War.

\section{Discussion}

The problem of each form of content analysis is simply that the content of media messages is not free from problems. The material under investigation is produced in a specific institutional context (e. g., a newspaper's editorial office) and refers to a wider socio-cultural context (e.g., The Netherlands in 1997). Usually, this material is read in a quite different context, namely from the perspective of the researcher posing his research questions (e.g., newspapers' portrayals of Dutch and German people). An adequate method of content analysis therefore involves attending to the content of material studied. However, the socio-cultural environment of this material cannot be clearly defined and the research questions can be formulated from various perspectives. This means that the content of the material is in principle an open property which in every study must be closely specified in a framework and logic, which the researcher has to explicate (Krippendorf, 1980). The framework contains a link between the question posed and the material researched, based on a certain logic that is operationalized. Both have to be formalized, if we are to be able to define the reconstructed logic of research. In the case of qualitative content analysis the framework does tend to be expounded (Hijmans, 1996), while the logic most often receives scant attention (Pleijter, forthcoming).

This contribution presents an attempt to specify the logic of an interpretive form of qualitative content analysis that is focused on exploring and reconstructing image-setting elements in given texts. In this procedure the methodological principles of interpretive qualitative research were translated into a qualitative form of content analysis. Newspapers' image-setting, whose objects are the Dutch and German people and their respective countries, was conceived of as a sensitizing concept that needs to be saturated by a constant comparison of news coverage in strategically chosen situations (theoretical sampling), while attention was paid 
to common elements. For this purpose an eight-step-procedure was elaborated and applied by several researchers. First, a perspective was established from which an event covered by media reports was described. Subsequently, the researchers collected relevant textual fragments into a survey and compared the fragments from various vantage points (per series, per case, over all the cases, per newspaper, etc.).

One of the aspects that is particularly interesting in terms of the evaluation of the quality of the procedure is its reliability. The simplest way to establish this is to compare the observations of different researchers. Do two different observers select the same textual fragments in each news item as relevant for image-building? On the basis of our research practice the answer is both positive and negative. Concurrent selection does occur in the case of short items as few textual fragments are related to actors, themes and evaluations. In the case of larger news reports concurrence occurs much less often because many different textual fragments relate to the same actors, themes and evaluations. The question, however, is whether this fact impairs the reliability of the procedure. In news coverage, normally, a rather constant replication of image-setting elements seems to take place, and for the analysis at hand this means that it does not make a difference whether one or another fragment has been selected. Moreover, it is not necessary to take into account all of the relevant fragments because repetitions of the same elements do not contribute to the specification of the content of image-setting at all, instead, it could hinder the researchers' easy survey of the studied material. Reliability in the sense of completeness - with regard to the number of observations made - could generate problems for the formulation of the image sought, and concerns, thus, an aspect of validity.

Obviously, image-setting by newspapers is something that occurs by repetition throughout various news reports. Therefore, in case an element was omitted (e.g., an evaluative expression), we can expect that element to recur in other news items. Thus the tables with selected imagerelevant fragments represent first of all a constant repetition of the same elements or variations of the same latent themes.

In qualitative research - which usually lacks a fully elaborated analytical framework - reliability and validity cannot be tested independently of each other. The most important procedures for controlling qualitative research results are therefore replication and triangulation (Denzin, 1978; Smaling, 1987; Kirk and Miller, 1986) which combine conceptual (validity) and empirical (reliability) aspects. The aspect of replication is elaborated in the presented procedure through the comparison of imagesetting elements within reports and through a comparison of image-setting fragments between various news reports collected in case-specific surveys. Triangulation is elaborated in our procedure through the com- 
parison of findings within one case (in this case for instance state visits) with findings concerning other cases (such as football matches, business cooperation, etc.). Both procedures, replication as well as triangulation, lead us to the conclusion that newspapers' image-setting - for instance Dutch newspapers' image-setting towards Germany - tends to be always the same, but with varying subjects is manifested in different ways.

\section{Note}

1. The research project 'Kommentare und Berichte von der anderen Seite der Grenze. Zur Rolle der Printmedien im deutsch-niederländischen Grenzraum' (Projekt-Nr.05/ 08/99) was subsidised by EU funds of the INTERREG-II Programme; secretary and management functions of the international cooperation project of the Heinrich Heine University, Düsseldorf (Historisches Semiar VI) and the University of Nijmegen (Department of Communication) were supplied by the Center for German Studies, University of Nijmegen (CDS). German researchers involved in the project were Hein Hoebink, Uwe Pöhls and Grace Micah. Karsten Renckstorf, Fred Wester and Alexander Pleijter, as well as Jan van Megen (CDS) ran the Dutch side of the project.

\section{References}

Anderson, J. A. (1987). Communication Research: Issues and Methods. New York: MacGraw-Hill.

Altheide, D. L. (1987). Ethnografic content analysis. Qualitative Sociology, 10(1), $65-77$.

Alexander, V. D. (1994). The image of children in magazine advertisements from 1905 to 1990, Communication Research, 21(6), 742-765.

Dekker, H. and Aspeslag, R. (1999). Ein besonderes Verhältnis. Deutschland und die Niederlande, Baden-Baden: Nomos.

Deutchman, I. E. and Ellsion, A. (1999). A star is born: The roller coaster ride of Pauline Hanson in the news. Media, Culture and Society, 21, 33-50.

Denzin, N. K. (1978). The Research Act. Chicago., IL: Aldine.

Dunk, H. W. von der (1994). Twee buren, twee culturen, Amsterdam: Prometheus.

Früh, W. (2001). Inhaltsanalyse. Theorie und Praxis. Konstanz: UVK Verlag.

Glaser, B. G. (1978). Theoretical Sensitivity. Advances in the methodology of grounded theory, Mill Valley: Sociology press.

Glaser, B. G. and Strauss, A. L. (1967). The discovery of grounded theory, Chicago, IL: Aldine.

Hardt-Mautner, G. (1995). "How does one become a good European?" The British press and European integration. Discourse and Society, 6, 177-205.

Hijmans, E. (1996). Logic for Qualitative Media Content Analysis: A Typology. Communications, 21(1), 93-108.

Janssen, L. B. (1993). Bekend en onbemind. Het beeld van Duitsland en Duitsers onder jongeren van vijftien tot negentien jaar. 's-Gravenhage: Instituut Clingendael.

Jankowski, N. and Wester, F. (1991). The qualitative tradition in social science inquiry: Contributions to mass communication research. In K. B. Jensen and N. W. Jankowski (Eds.), A Handbook of qualitative methodologies for mass communication research. (pp. 44-74). London: Routledge. 
Kirk, J. and Miller, M. L. (1986). Reliability and validity in qualitative research. Beverley Hills, CA: Sage.

Krippendorff, K. (1980). Content Analysis. London: Sage.

Lindlof, T. R. (1995). Qualitative communication research methods. Thousand Oakes, CA: Sage.

Lupton, D. (1993). AIDS risk and heterosexuality in the Australian press. Discourse and Society, 4, 307-328.

McAllister, M. P. (1992). Comic books and AIDS. Journal of Popular Culture, 26(2), $1-24$.

Mellinger, W. M. (1992). Postcards from the edge of the color line: Images of African Americans in popular culture, 1893-1917. Symbolic Interaction, 15(4), 413-433.

Pleijter, A. (forthcoming). Opzet en uitvoering van kwalitative inhoudsanalyse in de communicatiewetenschap. Doctoral dissertation, University of Nijmegen.

Renckstorf, K. and Janssen, J. (Eds.). (1989). Erger dan Duitsers. Het beeld van Duitsers en Duitsland in de Nederlandse media. Nijmegen: ITS.

Renckstorf, K. and Lange, O. (1990). Niederländer über Deutsche. Eine empirische Studie zur Exploration des Bildes der Niederländer von Deutschen, Nijmegen: ITS.

Renckstorf, K. and Wester, F. (2001). The 'Media Use as Social Action' Approach: Theory, Methodology, and Research Evidence So Far. Communications, 26(4), 389-419.

Renckstorf, K., Wester, F., Pleijter, A., Hoebink, H., Pöhls, U., and Van Megen, J. (2004). Kommentare und Berichte von der anderen Seite der Grenze. Eine empirische Studie zur Berichterstattung der tagesaktuellen Printmedien im deutsch-niederländischen Grenzraum, 1946-1999. forthcoming.

Shaheen, J. (1994). Arab images in American comic books. Journal of Popular Culture, 28(1), 123-133.

Smaling, A. (1987). Methodologisch Objectiviteit en Kwalitatief Onderzoek. Lisse: Swets and Zeitlinger.

Spradley, J. P. (1980). Participant Observation. New York: Holt Rinehart Winston.

Strauss, A. L. (1987). Qualitative analysis for social scientists. New York: Cambridge University Press.

Strauss, A. L. and Corbin, J. (1990). Basics of Qualitative Research. Grounded Theory Procedures and Techniques. Newbury Park, CA: Sage.

Triece, M. E. (1999). The practical true woman. Reconciling women and work in popular mail-order magazines, 1900-1920. Critical Studies in Mass Communication, $16,42-62$.

Tudor, (1992).Them and Us: Story and stereotype in the World Cup coverage, European Journal of Communication, 11(3), 347-370.

Vavrus, M. (1998). Working the senate from outside in: The mediated construction of a feminist political campaign. Critical Studies in Mass Communication, 15, 213-235.

Waisbord, S. (1997). The narrative of exposés in South American journalism. Gazette, 59, 189-203.

Wester, F. (1995). Strategieën voor Kwalitatief onderzoek. Muiderberg: Coutinho.

Wester, F. and Peters, V. (2000). Qualitative Analysis: phases, techniques and computer use. In Ch. Pole and C. Burgess (Eds.), Cross cultural case study research. (pp. 139-164) New York: Elsevier-JAI Press.

Westheide, H.(1997). Trügerische Nähe. Niederländisch-deutsche Beziehungen in Geschichte, Sprache und Kultur, Münster: LIT Verlag.

Yin, R. K. (1994). Case Study Research. Design and Method. London: Sage. 